\title{
The diets of pregnant and post-pregnant women in different social groups in London and Edinburgh: energy, protein, fat and fibre
}

\author{
BY CLAIRE SCHOFIELD, ERICA WHEELER* AND JUDY STEWART \\ Department of Human Nutrition, London School of Hygiene and Tropical Medicine, \\ Keppel Street, London WCIE $7 H T$
}

(Received 12 February 1987 - Accepted 24 July 1987)

\begin{abstract}
1. Dietary records were obtained twice in pregnancy and once post-partum from 265 women from all social classes in London and Edinburgh.

2. The London women always had higher mean energy, protein, fat and fibre intakes. Significant betweenregion differences emerged.

3. Some between-social classes differences occurred, but were not consistently significant.

4. All mean energy and fibre intakes were lower, and protein and fat intakes were higher, than current recommendations.

5. Of lactating women $15 \%$ claimed to be dieting.

6. The percentage dietary energy derived from fat varied from 36 (in a dieting group) to 42 .
\end{abstract}

A number of studies of diet in pregnancy have been made in the UK (Smithells et al. 1977; Campbell-Brown, 1982; Doyle et al. 1982; Pickard, 1983), but the interaction of regional and social-class differences in intakes has not been explored. The only source of information about dietary differences between the North and South of the UK, other than anecdote, is the National Food Survey (Ministry of Agriculture Fisheries and Food (MAFF), 1985). This monitors household consumption rather than individual intake, and aggregates rural and urban information for Scotland.

Those workers who have examined nutrient intakes in various combinations of social classes have reported a distinct 'social-class gradient' (Thomson, 1959; Smithells et al. 1977; Whitehead et al. 1981; Doyle et al. 1982; Abraham et al. 1985). Birth weights in the UK are generally lower in social classes $5+6$ (Office of Population Censuses and Surveys (OPCS), 1985), and the perinatal death rate is higher (OPCS, 1984). It is pertinent to inquire whether differences occur between the diets of pregnant and post-partum women in the North and South of the UK, and whether the effects of the 'social-class gradient' are similar in both regions. Between 1983 and 1985, a survey of the diets and food habits of pregnant and post-partum women was conducted simultaneously in London and Edinburgh; the present paper reports their energy, protein, fat and dietary fibre intakes, and compares them with some current recommendations (Department of Health and Social Security (DHSS), 1979; National Advisory Committee on Nutrition Education (NACNE), 1983). Intakes of other nutrients will be reported subsequently.

\section{METHODS}

The sample

The sample was drawn from white women, aged 17-36 years, in the first trimester of pregnancy, attending the antenatal clinics of St George's Hospital, London, The Simpson Memorial Maternity Pavilion, Edinburgh and Sighthill Health Centre, Edinburgh. Subjects

* For reprints 
Table 1. Design of study of diet in pregnancy

\begin{tabular}{|c|c|c|c|c|c|c|}
\hline \multirow[b]{2}{*}{ Round } & \multirow[b]{2}{*}{ Group } & \multicolumn{2}{|c|}{$\begin{array}{l}\text { No. of completed } \\
\text { diet records }\end{array}$} & \multirow[b]{2}{*}{ Period } & \multirow[b]{2}{*}{ Process } & \multirow[b]{2}{*}{ Location } \\
\hline & & London & Edinburgh & & & \\
\hline - & - & - & 一 & $<14$ weeks pregnant & $\begin{array}{l}\text { Introductory letter, } \\
\text { recruitment } \\
\text { questionnaire } \\
\text { Round I visit booked }\end{array}$ & Ante-natal clinic \\
\hline 1 & la & 53 & 85 & $\begin{array}{l}<14 \text { weeks pregnant } \\
(\text { trimester } 1)\end{array}$ & & \\
\hline 1 & $1 \mathrm{~b}$ & 84 & 38 & $\left.\begin{array}{c}15-28 \text { weeks } \\
\text { (trimester } 2)\end{array}\right\}$ & $2 \mathrm{~d}$ food diary & Own home \\
\hline 2 & 2 & 110 & 107 & $\begin{array}{l}32-40 \text { weeks } \\
\text { (trimester 3) }\end{array}$ & $\begin{array}{l}3 \mathrm{~d} \text { weighed } \\
\text { inventory }\end{array}$ & Own home \\
\hline 3 & $3 \mathrm{~L}$ & 22 & 33 & $\begin{array}{c}>2 \text { months post- } \\
\text { partum lactating }\end{array}$ & & \\
\hline 3 & $3 \mathrm{NL}$ & 102 & 77 & $\begin{array}{l}>2 \text { months post- } \\
\text { partum not } \\
\text { lactating }\end{array}$ & $3 \mathrm{~d}$ food diary & Own home \\
\hline
\end{tabular}

were excluded if they had any record of chronic disease such as hypertension, heart or kidney disease, or of gross obstetric abnormality.

Quota sampling was used to ensure similar numbers of subjects from all social classes, which were determined by the partner's occupation (OPCS, 1980), or by the woman's own occupation if she had no regular cohabitee. A number of women were still lactating at the final interview, and several claimed to be dieting in order to lose weight. Those women who were neither dieting nor lactating at the post-partum interview were regarded as a nonpregnant control group. The study design is summarized in Table 1 . Women were recruited initially into group 1a or group $1 \mathrm{~b}$. All these formed group 2, and membership of groups $3 \mathrm{~L}$ and $3 \mathrm{NL}$ was determined by the women's feeding practice.

\section{Dietary intake}

A combination of diary-keeping and food weighing (Marr, 1971) was chosen so as to allow the consistent recording of food intake throughout pregnancy and into the post-partum period. All records included one weekend day. Two methods were used.

Estimated food record (food diary). Subjects kept a diary of all foods and drink consumed, in terms of household measures with recipes given where appropriate. These were converted into weights using a 'catalogue' of weighed food portions (Dunn Nutrition Unit, Cambridge). This method, being easier for the subject to manage, was used for $2 \mathrm{~d}$ in early pregnancy when subjects were most likely to be suffering from nausea and vomiting, and for $3 \mathrm{~d}$ post-partum, when they were dealing with a young infant.

Weighed inventory. Subjects weighed all prepared food before consumption, and plate waste after the meal, using Salter compression spring balances (no. 511 ) calibrated in $5 \mathrm{~g}$ divisions. Subjects were asked to give details of recipes used in home cooking. This method was used for $3 \mathrm{~d}$ in late pregnancy, when most women had stopped working and were able to cope with weighing food.

The food diary and weighed inventory record books contained detailed written instructions, and verbal instructions were also given. In addition, women were asked whether they experienced cravings and aversions with regard to specific foods, during pregnancy. 
Table 2. Distribution of the subjects by social class

\begin{tabular}{|c|c|c|c|c|c|c|c|c|}
\hline \multirow[b]{2}{*}{ Social class* } & \multicolumn{4}{|c|}{ London } & \multicolumn{4}{|c|}{ Edinburgh } \\
\hline & $n$ & $\%$ & $n$ & $\%$ & $n$ & $\%$ & $n$ & $\%$ \\
\hline $\begin{array}{l}1 \\
2\end{array}$ & $\begin{array}{l}20 \\
27\end{array}$ & $\left.\begin{array}{l}14 \\
20\end{array}\right\}$ & 47 & 34 & $\begin{array}{l}19 \\
26\end{array}$ & $\left.\begin{array}{l}15 \\
20\end{array}\right\}$ & 45 & 35 \\
\hline $\begin{array}{l}3 \\
4\end{array}$ & $\begin{array}{l}31 \\
41\end{array}$ & $\left.\begin{array}{l}22 \\
30\end{array}\right\}$ & 72 & 52 & $\begin{array}{l}15 \\
29\end{array}$ & $\left.\begin{array}{l}12 \\
23\end{array}\right\}$ & 44 & 35 \\
\hline $\begin{array}{l}5 \\
6\end{array}$ & $\begin{array}{r}11 \\
8\end{array}$ & $\left.\begin{array}{l}8 \\
6\end{array}\right\}$ & 19 & 14 & $\begin{array}{l}25 \\
13\end{array}$ & $\left.\begin{array}{l}20 \\
10\end{array}\right\}$ & 38 & 30 \\
\hline All & -- & - & 138 & - & - & - & 127 & - \\
\hline
\end{tabular}

* Non manual: 1, professional; 2, management and technical; 3, clerical and minor supervisory; manual: 4, skilled manual; 5, semi-skilled manual; 6, unskilled manual (Office of Population Censuses and Surveys, 1980).

Validation tests were devised to ensure the comparability of $2 \mathrm{~d}$ and $3 \mathrm{~d}$ diaries with each other and the weighed inventories. Two approaches were used:

Comparison of 2 and 3 d estimated food records. Correlation coefficients were calculated between 2 and $3 \mathrm{~d}$ means for energy and nutrient intakes in round 3 . The days were aggregated in four ways: as the mean of days $1+2,2+3,3+1$ and of a randomly selected pair of days. These four mean values were each regressed on the $3 \mathrm{~d}$ mean. The correlation coefficients ranged from 0.91 to 0.97 . It was concluded that comparison between 2 and $3 \mathrm{~d}$ records was acceptable for this sample, and that valid comparisons between rounds 1 and 3 could therefore be made.

Comparison of estimated food record and weighed inventory. In the third trimester (round 2), twenty (15\%) subjects provided estimated food records instead of weighed inventories. There was no social class or age bias in this subgroup. For each location, the mean intakes by the two methods were compared by Student's $t$ test for independent samples: no statistically significant differences were detected. It was concluded that the weighed inventory and estimated food record methods were producing comparable results, and that valid comparisons between round 2 and rounds 1 and 3 could be made.

\section{Statistical analysis}

The weighed food intake record books and food diaries were coded using food tables (Paul \& Southgate, 1978; Paul et al. 1980). Computation of energy and nutrient intakes was done at the MAFF, using purpose-written dietary-survey software. Statistical methods included the use of logarithmic transformations of nutrient intakes with skewed distributions, Student's $t$ test on the means of raw and transformed variables, and the $Z$ test of difference between sample proportions (Snedecor \& Cochran, 1967).

The study was approved by the ethical committees of St George's Hospital, London, and the Royal Infirmary, Edinburgh.

\section{RESULTS}

Sample and records

Post-recruitment drop-out rates were 4\% (London) and $9 \%$ (Edinburgh). Incomplete records were omitted. Values were aggregated into three social groups as shown in Table 2 , to allow comparison of extremes of the social range, and across the social gradient. The study continued for 20 months and the average number of subjects participating in each 


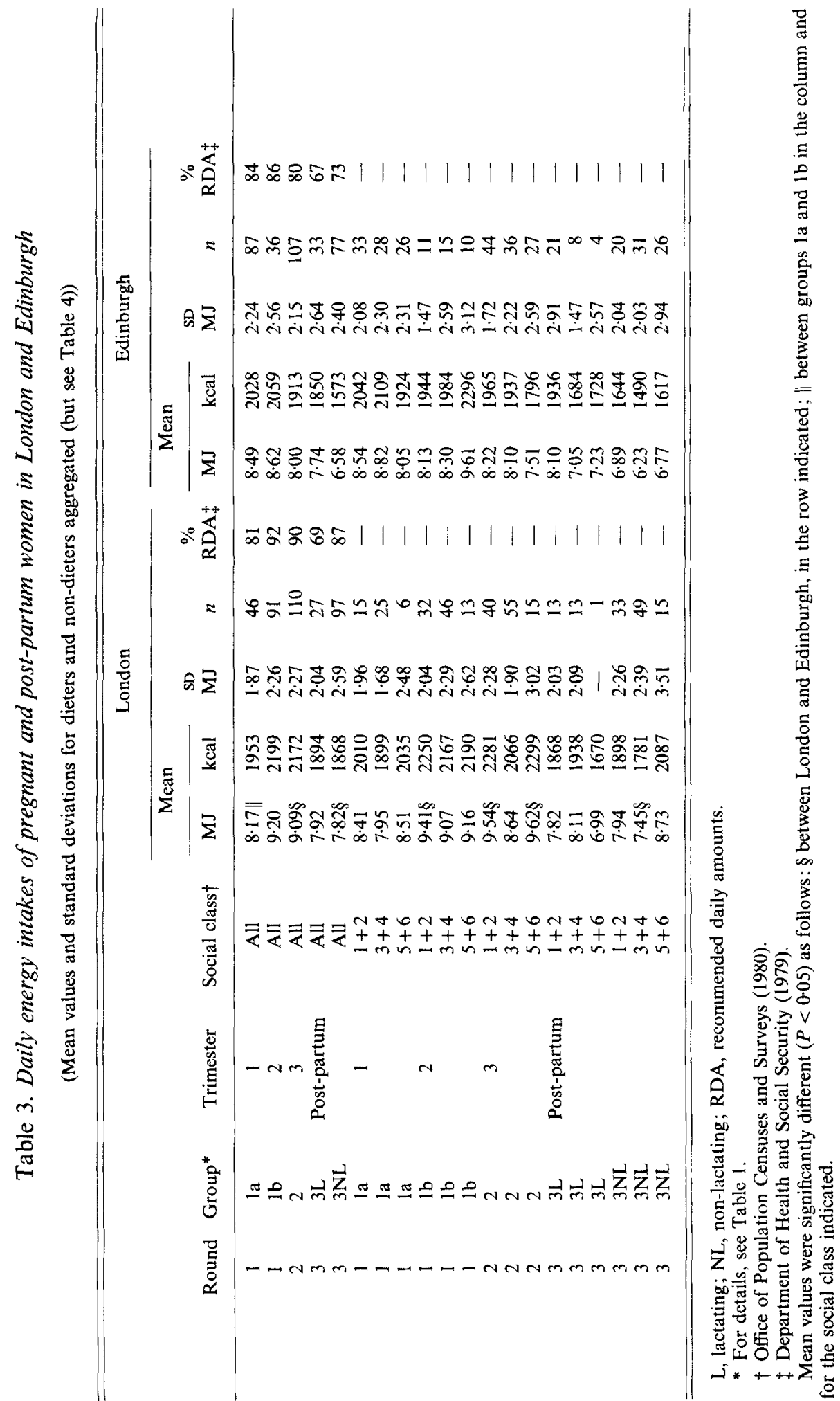


Table 4. Daily post-partum energy, protein and fat intakes of 'dieting' and 'non-dieting' women in London and Edinburgh

(Mean values and standard deviations)

\begin{tabular}{|c|c|c|c|c|c|c|c|c|}
\hline & \multirow[b]{2}{*}{$n$} & \multicolumn{2}{|c|}{$\begin{array}{c}\text { Energy MJ } \\
(\text { kcal })\end{array}$} & \multicolumn{2}{|c|}{ Protein $(\mathrm{g})$} & \multicolumn{2}{|c|}{ Fat $(\mathrm{g})$} & \multirow{2}{*}{$\begin{array}{l}\% \text { Energy } \\
\text { from fat }\end{array}$} \\
\hline & & Mean & SD & Mean & $\mathrm{SD}$ & Mean & SD & \\
\hline \multicolumn{9}{|l|}{ London } \\
\hline \multicolumn{9}{|l|}{ Lactating: } \\
\hline Dieting & 6 & $\begin{array}{r}6.36^{*} \\
(1521)\end{array}$ & $\begin{array}{r}2.76 \\
(660)\end{array}$ & $56 \cdot 7$ & $19 \cdot 8$ & $60 \cdot 2^{*}$ & $28 \cdot 0$ & 36 \\
\hline Non-dieting & 21 & $\begin{array}{c}8 \cdot 37 \\
(2001)\end{array}$ & $\begin{array}{c}1.66 \\
(397)\end{array}$ & $72 \cdot 6$ & $13 \cdot 0$ & $88 \cdot 9$ & $18 \cdot 2$ & 40 \\
\hline \multicolumn{9}{|l|}{ Non-lactating: } \\
\hline Dieting & 20 & $\begin{array}{r}6.05^{*} \\
(1447)\end{array}$ & $\begin{array}{c}2 \cdot 14 \\
(512)\end{array}$ & $56 \cdot 1^{*}$ & $13 \cdot 2$ & $60 \cdot 8^{*}$ & $21 \cdot 8$ & 38 \\
\hline Non-dieting & 77 & $\begin{array}{r}8.24 \dagger \\
(1970)\end{array}$ & $\begin{array}{c}2.56 \\
(611)\end{array}$ & $68 \cdot 4$ & $18 \cdot 7$ & $90 \cdot 6 \dagger$ & $32 \cdot 7$ & 41 \\
\hline \multicolumn{9}{|l|}{ Edinburgh } \\
\hline \multicolumn{9}{|l|}{ Lactating: } \\
\hline Dieting & 3 & $\begin{array}{c}6.83 \\
(1633)\end{array}$ & $\begin{array}{c}1.70 \\
(407)\end{array}$ & $66 \cdot 4$ & $4 \cdot 3$ & $67 \cdot 7$ & $19 \cdot 0$ & 37 \\
\hline Non-dieting & 30 & $\begin{array}{c}7.83 \\
(1871)\end{array}$ & $\begin{array}{r}2.76 \\
(659)\end{array}$ & $69 \cdot 2$ & 31.0 & 83.7 & $34 \cdot 5$ & 40 \\
\hline \multicolumn{9}{|l|}{ Non-lactating: } \\
\hline Dieting & 21 & $\begin{array}{c}6.48 \\
(1548)\end{array}$ & $\begin{array}{c}2.46 \\
(587)\end{array}$ & $62 \cdot 1$ & $17 \cdot 6$ & $74 \cdot 0$ & $33 \cdot 2$ & 43 \\
\hline Non-dieting & 56 & $\begin{array}{c}6.62 \\
(1582)\end{array}$ & $\begin{array}{c}2.41 \\
(577)\end{array}$ & $58 \cdot 8$ & 20.9 & $72 \cdot 9$ & $27 \cdot 4$ & 42 \\
\hline
\end{tabular}

* Differences between dieting and non-dieting means in the same subgroup were significant $(P<0.05)$.

$\dagger$ Differences between London and Edinburgh means for the same subgroup were significant $(P<0.05)$.

month was fifty-nine. The reported incidence of nausea during the first and second trimesters was $76 \%$ in London and $51 \%$ in Edinburgh. In the third trimester, 24 and $8 \%$ respectively reported nausea. Post-partum, twenty-six women in London and twenty-four in Edinburgh claimed to be dieting in an attempt to lose weight.

During the first two trimesters, fifty-nine (55\%) in Edinburgh and ninety-three $(69 \%)$ in London reported cravings for specific foods, and sixty-two (58\%) in Edinburgh and 116 $(86 \%)$ in London reported aversions. The between-region differences between the proportions in each case were statistically significant $(\mathrm{Z}$ test, $P<0 \cdot 05$ ). The proportions reporting nausea in round 1 were also significantly different.

\section{Energy}

Table 3 shows mean energy intakes throughout the study. Few between-social class differences emerged. The lowest intake during pregnancy was that of social classes $5+6$ in Edinburgh in the third trimester $(7.5 \mathrm{MJ}(1796 \mathrm{kcal}) / \mathrm{d}$. In London it was social classes $3+4$ which consistently had the lowest energy intake, although these differences were not statistically significant. Post-partum, the only significant difference detected was in Edinburgh, between social classes $1+2$ and $3+4(P<0 \cdot 01)$.

In London, all social classes combined, energy intake was greater by over $0.9 \mathrm{MJ}$ $(220 \mathrm{kcal}) / \mathrm{d}$ in the second than in the first trimester, with no difference for the rest of pregnancy. The post-partum energy intakes of both lactating and non-lactating London women were less than those during pregnancy. Table 4 shows the mean values after 
Table 5. Daily protein intakes $(g)$ of pregnant and post-pregnant women in London and Edinburgh

(Mean values and standard deviations for dieters and non-dieters aggregated (but see Table 4))

\begin{tabular}{|c|c|c|c|c|c|c|c|c|c|}
\hline \multirow[b]{2}{*}{ Round } & \multirow[b]{2}{*}{ Group* } & \multirow[b]{2}{*}{ Trimester } & \multirow{2}{*}{$\begin{array}{l}\text { Social } \\
\text { class } \dagger\end{array}$} & \multicolumn{3}{|c|}{ London } & \multicolumn{3}{|c|}{ Edinburgh } \\
\hline & & & & Mean & SD & $n$ & Mean & SD & $n$ \\
\hline 1 & la & 1 & All & $69 \cdot 6$ & $17 \cdot 2$ & 46 & $72 \cdot 5$ & $22 \cdot 7$ & 87 \\
\hline 1 & lb & 2 & All & $78 \cdot 8 \div$ & 20.5 & 91 & $67 \cdot 6$ & $19 \cdot 6$ & 36 \\
\hline 2 & 2 & 3 & All & $77.6 t$ & $20 \cdot 8$ & 110 & $68 \cdot 6$ & $17 \cdot 7$ & 107 \\
\hline 3 & $3 \mathrm{~L}$ & Post-partum & All & $69 \cdot 1^{\circ}$ & $15 \cdot 6$ & 27 & $68 \cdot 9$ & $29 \cdot 1$ & 33 \\
\hline 3 & $3 \mathrm{NL}$ & & All & $65.1+$ & $18 \cdot 2$ & 97 & $59 \cdot 7$ & 19.8 & 77 \\
\hline 1 & la & 1 & $\mathrm{I}+2$ & $72 \cdot 5^{\circ}$ & $16 \cdot 1$ & 15 & $75 \cdot 4$ & $20 \cdot 5$ & 33 \\
\hline 1 & la & & $3+4$ & $69 \cdot 1$ & 16.5 & 25 & $74 \cdot 6$ & $23 \cdot 8$ & 28 \\
\hline 1 & la & & $5+6$ & $64 \cdot 5$ & $21 \cdot 1$ & 6 & $66 \cdot 4$ & $22 \cdot 8$ & 26 \\
\hline 1 & $1 b$ & 2 & $1+2$ & $84 \cdot 5$ & $21 \cdot I$ & 32 & $72 \cdot 2$ & $12 \cdot 6$ & 11 \\
\hline 1 & $1 b$ & & $3+4$ & 76.5 & $19 \cdot 4$ & 46 & $66 \cdot 4$ & $23 \cdot 4$ & 15 \\
\hline 1 & $\mathrm{lb}$ & & $5+6$ & $73 \cdot 3$ & $19 \cdot 7$ & 13 & $65 \cdot 4$ & $19 \cdot 2$ & 10 \\
\hline 2 & 2 & 3 & $1+2$ & $83 \cdot 6 t$ & $18 \cdot 6$ & 40 & $72 \cdot 8$ & $12 \cdot 5$ & 44 \\
\hline 2 & 2 & & $3+4$ & $72 \cdot 2 \S$ & $17 \cdot 6$ & 55 & $68 \cdot 6$ & $19 \cdot 8$ & 36 \\
\hline 2 & 2 & & $5+6$ & $81 \cdot 2 \ddagger$ & $30 \cdot 3$ & 15 & $61 \cdot 7 \S$ & 19.8 & 27 \\
\hline 3 & $3 \mathrm{~L}$ & Post-partum & $1+2$ & $70 \cdot 5^{\top}$ & $17 \cdot 4$ & 13 & $72 \cdot 7^{\circ}$ & $32 \cdot 0$ & 21 \\
\hline 3 & $3 \mathrm{~L}$ & & $3+4$ & $68 \cdot 1$ & $14 \cdot 0$ & 13 & $60 \cdot 4$ & $9 \cdot 7$ & 8 \\
\hline 3 & $3 \mathrm{~L}$ & & $5+6$ & $63 \cdot 4$ & - & 1 & $65 \cdot 9$ & $34 \cdot 5$ & 4 \\
\hline 3 & $3 \mathrm{NL}$ & & $1+2$ & 67.9 & $15 \cdot 3$ & 33 & 65.9 & 17.8 & 20 \\
\hline 3 & 3NL & & $3+4$ & $63 \cdot 7$ & 16.6 & 49 & $59 \cdot 6$ & 18.8 & 31 \\
\hline 3 & $3 N L$ & & $5+6$ & $68 \cdot 6$ & $26 \cdot 5$ & 15 & $55 \cdot 1$ & $21 \cdot 2$ & 26 \\
\hline
\end{tabular}

L, lactating; NL, non-lactating.

* For details, see Table 1.

$\dagger$ Office of Population Censuses and Surveys (1980).

Mean values were significantly different $(P<0.05)$ as follows: $\ddagger$ between London and Edinburgh, in the row indicated; $\S$ from value for social classes $1+2$ in the survey round indicated.

separation of the values for those subjects who claimed post-partum dieting. Statistical significance was achieved when mean intakes of the London dieting and non-dieting women were compared. The lowest mean energy intake in the survey was that of the London nonlactating, dieting group: 60 (SE 2.0) MJ (1447 (SE 512) kcal)/d. In Edinburgh, all social classes combined, mean intakes were slightly lower after the second trimester, and fell postpartum. Dieting, lactating subjects had a low mean intake, similar to that of non-lactating dieters.

In summary, the Londoners consumed significantly more energy than the Scots in all social classes in trimester 3 , and for non-lactating women. The same regional difference existed, but was not significant, in the first two trimesters, and for lactating women. Significant between-region differences were shown by social classes $1+2$, in trimesters 2 and 3 , when the London intakes again were the higher.

\section{Protein}

There were no significant between-social class differences in protein intake in London, but in Edinburgh during the third trimester and post-partum, social classes $1+2$ consumed significantly more protein than classes $5+6$. The mean London protein intake rose in the second trimester and remained high in the third (Table 5). All the post-partum intakes were similar to that of the first trimester. In Edinburgh, mean protein intakes remained constant 
Table 6. Daily fat intakes $(\mathrm{g})$ of pregnant and post-pregnant women in London and Edinburgh

(Mean values and standard deviations for dieters and non-dieters aggregated (but see Table 4))

\begin{tabular}{|c|c|c|c|c|c|c|c|c|c|}
\hline \multirow[b]{2}{*}{ Round } & \multirow[b]{2}{*}{ Group* } & \multirow[b]{2}{*}{ Trimester } & \multirow{2}{*}{$\begin{array}{l}\text { Social } \\
\text { classt }\end{array}$} & \multicolumn{3}{|c|}{ London } & \multicolumn{3}{|c|}{ Edinburgh } \\
\hline & & & & Mean & SD & $n$ & Mean & SD & $n$ \\
\hline 1 & 1a & 1 & All & $85 \cdot 4$ & $25 \cdot 8$ & 46 & $92 \cdot 0$ & $31 \cdot 4$ & 87 \\
\hline 1 & $1 \mathrm{~b}$ & 2 & All & $97 \cdot 9$ & 31.8 & 91 & $94 \cdot 5$ & $31 \cdot 8$ & 36 \\
\hline 2 & 2 & 3 & All & $94 \cdot 7 \ddagger$ & $27 \cdot 0$ & 110 & $84 \cdot 7$ & $26 \cdot 1$ & 107 \\
\hline 3 & $3 \mathrm{~L}$ & Post-partum & All & $82 \cdot 5$ & $23 \cdot 1$ & 27 & $82 \cdot 2$ & $33 \cdot 0$ & 33 \\
\hline 3 & $3 \mathrm{NL}$ & & All & $84 \cdot 5 \ddagger$ & 32.8 & 97 & $73 \cdot 2$ & $28 \cdot 7$ & 77 \\
\hline 1 & la & 1 & $1+2$ & $89 \cdot 7^{+}$ & $28 \cdot 5$ & 15 & $92 \cdot 7$ & $26 \cdot 6$ & 33 \\
\hline 1 & la & & $3+4$ & $81 \cdot 6 t$ & 22.2 & 25 & $98 \cdot 4$ & $33 \cdot 9$ & 28 \\
\hline 1 & $1 a$ & & $5+6$ & $90 \cdot 5^{+}$ & 29.4 & 6 & $84 \cdot 1$ & $32 \cdot 4$ & 26 \\
\hline 1 & Ib & 2 & $1+2$ & $100 \cdot 6$ & $27 \cdot 6$ & 32 & $91 \cdot 4$ & $17 \cdot 6$ & 11 \\
\hline 1 & Ib & & $3+4$ & $95 \cdot 0$ & $29 \cdot 6$ & 46 & $92 \cdot 6$ & $32 \cdot 1$ & 15 \\
\hline 1 & lb & & $5+6$ & $101 \cdot 1+$ & $39 \cdot 3$ & 15 & $77 \cdot 2$ & 26.6 & 27 \\
\hline 2 & 2 & 3 & $1+2$ & 98.5 & 26.2 & 40 & $88 \cdot 4$ & $23 \cdot 0$ & 44 \\
\hline 2 & 2 & & $3+4$ & $90 \cdot 2$ & $22 \cdot 3$ & 55 & $85 \cdot 9$ & $28 \cdot 2$ & 36 \\
\hline 2 & 2 & & $5+6$ & $101 \cdot 1 \ddagger$ & $39 \cdot 3$ & 15 & $77 \cdot 2$ & $26 \cdot 6$ & 27 \\
\hline 3 & $3 \mathrm{~L}$ & Post-partum & $1+2$ & 77.6 & $21 \cdot 2$ & 13 & $85 \cdot 5$ & $36 \cdot 9$ & 21 \\
\hline 3 & $3 \mathrm{~L}$ & & $3+4$ & 86.5 & $24 \cdot 6$ & 13 & $74 \cdot 3$ & $13 \cdot 3$ & 8 \\
\hline 3 & $3 \mathrm{~L}$ & & $5+6$ & $94 \cdot 3$ & - & 1 & $80 \cdot 9$ & $36 \cdot 3$ & 4 \\
\hline 3 & $3 \mathrm{NL}$ & & $1+2$ & $89 \cdot 2$ & $35 \cdot 8$ & 33 & $77 \cdot 9$ & $27 \cdot 0$ & 20 \\
\hline 3 & $3 \mathrm{NL}$ & & $3+4$ & $78 \cdot 4$ & 26.9 & 49 & $70 \cdot 3$ & $26 \cdot 5$ & 31 \\
\hline 3 & $3 \mathrm{NL}$ & & $5+6$ & $94 \cdot 0$ & 38.8 & 15 & $73 \cdot 1$ & 31.8 & 26 \\
\hline
\end{tabular}

L, lactating; NL, non-lactating.

* For details, see Table 1.

+ Office of Population Censuses and Surveys (1980).

Mean values were significantly different $(P<0.05)$ as follows: $¥$ between London and Edinburgh in the row indicated.

through pregnancy, and were low in the non-lactating, post-partum group. The lowest intake was that of the non-lactating, dieting group (Table 4).

In summary, the London women consumed more protein than the Edinburgh group during the second and third trimesters and in the non-lactating groups, in all social groups. 'Dieting' women in Edinburgh (Table 4) had mean protein intakes which were greater than those of the Londoners.

\section{Fat}

No significant differences in absolute fat consumption or in fat as a percentage of total energy could be detected among social class groups in London or Edinburgh. During pregnancy, percentage energy from fat varied between 39 and $42 \%$. Post-partum values are shown in Table 4 , the lowest (36\%) being for London dieters. The mean fat intake of the pregnant London group was higher in the second trimester and remained high during the third trimester (Table 6). Fat intakes were lower post-partum. The effect of removing dieting subjects from the aggregated mean values for both lactating and non-lactating groups was marked (Table 4) with the mean intake of non-dieters greater by $6 \mathrm{~g} / \mathrm{d}$. In Edinburgh, fat intakes were slightly higher in the third trimester, but lower post-partum. Lactating subjects consumed on average a larger amount of fat than those not lactating, but the differences were not statistically significant.

In summary, the London group consumed significantly more fat than the Edinburgh 
Table 7. Daily fibre intakes ( $g$ ) of pregnant and post-pregnant women in London and Edinburgh

(Geometric mean values and standard deviations for dieters and non-dieters aggregated)

\begin{tabular}{|c|c|c|c|c|c|c|c|c|c|}
\hline \multirow[b]{2}{*}{ Round } & \multirow[b]{2}{*}{ Group* } & \multirow[b]{2}{*}{ Trimester } & \multirow[b]{2}{*}{$\begin{array}{l}\text { Social } \\
\text { class } \dagger\end{array}$} & \multicolumn{3}{|c|}{ London } & \multicolumn{3}{|c|}{ Edinburgh } \\
\hline & & & & $\begin{array}{c}\text { Geometric } \\
\text { mean }\end{array}$ & SD & $n$ & $\begin{array}{c}\text { Geometric } \\
\text { mean }\end{array}$ & $\mathrm{SD}$ & $n$ \\
\hline 1 & la & I & All & $18.9 \pm$ & 1.52 & 46 & $15 \cdot 8$ & 1.51 & 87 \\
\hline 1 & $1 b$ & 2 & Ail & $19.9 \ddagger$ & 1.43 & 91 & 15.1 & 1.60 & 36 \\
\hline 2 & $2 \mathrm{~L}$ & 3 & All & $19 \cdot 0 \ddagger$ & 1.47 & 110 & 146 & 1.45 & 107 \\
\hline 3 & $3 \mathrm{~L}$ & Post-partum & All & $19 \cdot 1+$ & $1 \cdot 36$ & 27 & $15 \cdot 3$ & 1.50 & 33 \\
\hline 3 & $3 N L$ & & All & $16 \cdot 3 \ddagger$ & 1.51 & 97 & 11.5 & 1.52 & 77 \\
\hline 1 & la & 1 & $1+2$ & $21 \cdot 5 \ddagger$ & 1.65 & 15 & $18 \cdot 2$ & 1.56 & 33 \\
\hline 1 & la & & $3+4$ & $19 \cdot 1 \neq \$$ & $1 \cdot 34$ & 25 & $15.8 \S$ & 1.46 & 28 \\
\hline 1 & 1a & & $5+6$ & $13.0 \S$ & $1 \cdot 54$ & 6 & $13 \cdot 3 \S$ & 1.40 & 26 \\
\hline$i$ & $1 \mathrm{~b}$ & 2 & $1+2$ & $23 \cdot 4$ & 1.39 & 32 & $16 \cdot 5$ & 1.38 & 11 \\
\hline 1 & $1 \mathrm{~b}$ & & $3+4$ & $18 \cdot 2 \ddagger \S$ & 1.32 & 46 & 13.7 & 1.79 & 15 \\
\hline 1 & $1 \mathrm{~b}$ & & $5+6$ & $17.9 \pm \S$ & 1.45 & 13 & $15 \cdot 8$ & 1.47 & 10 \\
\hline 2 & 2 & 3 & $1+2$ & $21 \cdot 0^{+0}$ & 1.47 & 40 & $15 \cdot 8$ & $1 \cdot 32$ & 44 \\
\hline 2 & 2 & & $3+4$ & $17 \cdot 9$ & 1.43 & 55 & $15 \cdot 4$ & 1.41 & 36 \\
\hline 2 & 2 & & $5+6$ & $18 \cdot 5$ & 1.53 & 15 & $12 \cdot 78$ & 1.57 & 27 \\
\hline 3 & $3 \mathrm{~L}$ & Post-partum & $1+2$ & $21.0+$ & 1.40 & 13 & $16.9^{8}$ & 1.56 & 21 \\
\hline 3 & $3 \mathrm{~L}$ & & $3+4$ & $17 \cdot 3 \ddagger$ & 1.29 & 13 & $13 \cdot 6$ & $1 \cdot 31$ & 8 \\
\hline 3 & $3 \mathrm{~L}$ & & $5+6$ & $18 \cdot 5^{+}$ & - & 1 & $12 \cdot 0$ & - & 4 \\
\hline 3 & $3 N L$ & & $1+2$ & $16 \cdot 3 \ddagger$ & 1.45 & 33 & $12 \cdot 1$ & $1 \cdot 34$ & 20 \\
\hline 3 & $3 \mathrm{NL}$ & & $3+4$ & $16 \cdot 3^{+}$ & 1.47 & 49 & $11 \cdot 1$ & $1-48$ & 31 \\
\hline 3 & $3 \mathrm{NL}$ & & $5+6$ & $16 \cdot 3 t$ & 1.72 & 15 & $11 \cdot 5$ & 1.67 & 26 \\
\hline
\end{tabular}

L, lactating; NL, non-lactating.

* For details, see Table 1.

$\dagger$ Office of Population Censuses and Surveys (1980).

Mean values were significantly different $(P<0.05)$ as follows: $\ddagger$ between London and Edinburgh in the row indicated; $\S$ from value for social classes $1+2$ in the survey round indicated.

group in the third trimester and in the non-lactating group. In London, but not in Edinburgh, 'dieting' women consumed less fat. These effects were common to all social groups.

\section{Fibre}

Fibre intakes were positively skewed, so logarithmic transformations were employed. The geometric means and standard deviations are given in Table 7. The trend in fibre intake (Table 7) was the same in London and Edinburgh: fairly constant during pregnancy and lactation, and higher than the post-partum intake of the non-lactating women. Regional comparisons showed that in all social classes in every round, the Londoners ate significantly more fibre than their Scottish counterparts $(P<0.05)$. In London, social classes $1+2$ ate more than classes $3+4$ and $5+6$ in the first and second trimesters. In Edinburgh, social classes $1+2$ ate more fibre than classes $5+6$ in the first and third trimesters.

\section{DISCUSSION}

The mean intakes of the subjects in the present study have been compared with the recommended daily amounts (RDA) which are currently in use for the UK. The DHSS (1979) has published RDA for energy, protein and other nutrients, sufficient for the 
Diets of pregnant and post-pregnant women

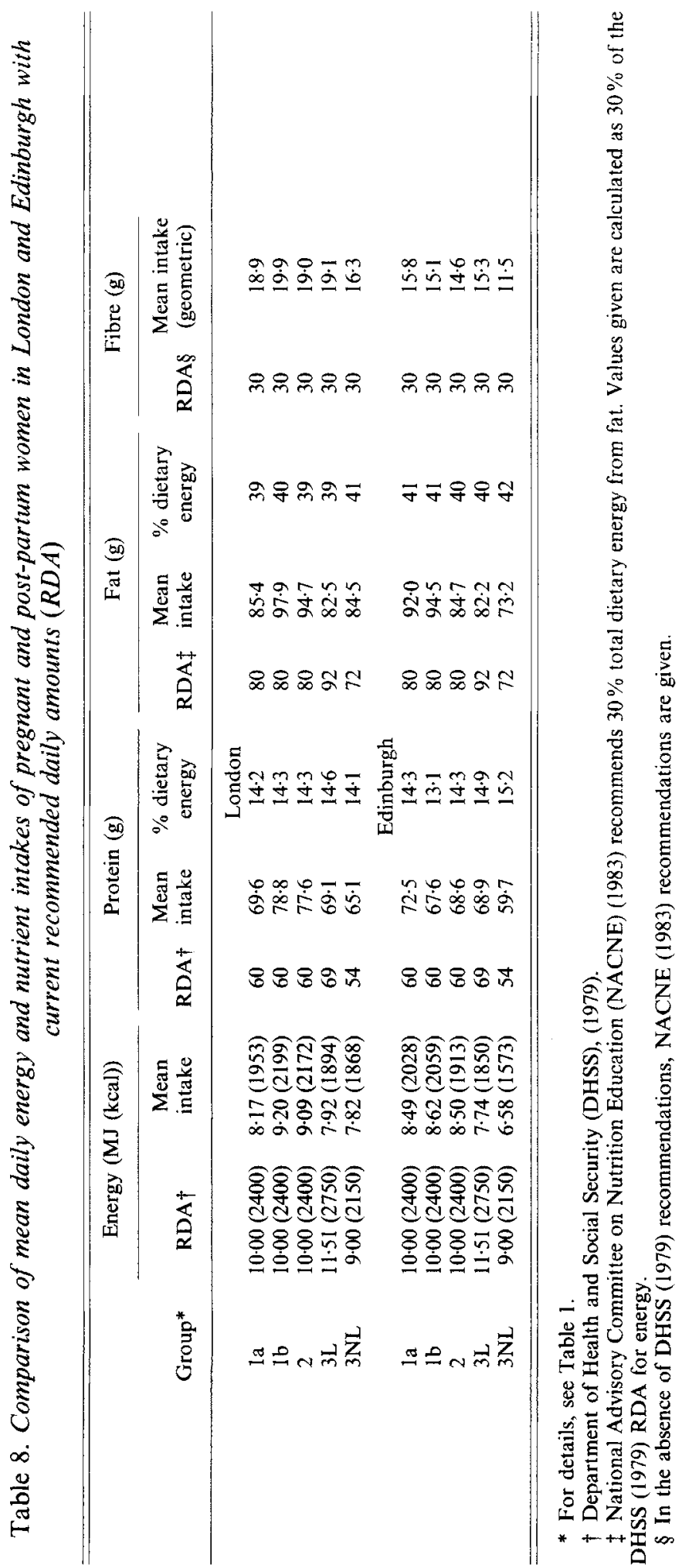


Table 9. Mean daily energy intakes $(M J)$ reported in various $U K$ studies of pregnant and lactating women during the past 40 years

\begin{tabular}{|c|c|c|c|c|c|c|}
\hline \multirow[b]{2}{*}{ Year } & \multirow{2}{*}{$\begin{array}{l}\text { Location/ } \\
\text { social class }\end{array}$} & \multicolumn{3}{|c|}{$\begin{array}{l}\text { Pregnancy } \\
\text { trimester }\end{array}$} & \multirow[b]{2}{*}{ Lactation } & \multirow[b]{2}{*}{ Source } \\
\hline & & 1 & 2 & 3 & & \\
\hline 1944 & London/poor & - & - & - & $9 \cdot 7-11 \cdot 0$ & Bransby et al. (1944) \\
\hline 1958 & $\begin{array}{l}\text { Aberdeen } / 1+2 \\
\text { Aberdeen } / 5+6\end{array}$ & - & - & $\begin{array}{r}11.0 \\
9.8\end{array}$ & - & Thomson (1959) \\
\hline 1970 & Aberdeen/mixed & - & - & - & $12 \cdot 4$ & Thomson el al. (1970) \\
\hline 1977 & $\begin{array}{l}\text { Leeds } / 1+2 \\
\text { Leeds } / 5+6\end{array}$ & $\begin{array}{l}9 \cdot 12 \\
8 \cdot 16\end{array}$ & - & - & - & Smithells et al. (1977) \\
\hline 1981 & Cambridge/1--3 & - & $8 \cdot 15$ & $8 \cdot 38$ & $9 \cdot 62$ & Whitehead et al. (1981) \\
\hline 1982 & London/"low' & 6.74 & $7 \cdot 21$ & $7 \cdot 41$ & - & Doyle et al. (1982) \\
\hline 1986 & $\begin{array}{l}\text { Cambridge/non-manual } \\
\text { Cambridge/manual }\end{array}$ & - & - & $\begin{array}{l}9 \cdot 02 \\
8 \cdot 04\end{array}$ & $\begin{array}{c}10 \cdot 3 \\
9 \cdot 33\end{array}$ & Black of al. (1986) \\
\hline 1986 & $\begin{array}{l}\text { Edinburgh } / 1+2 \\
\text { Edinburgh } / 5+6 \\
\text { London } / 1+2 \\
\text { London } / 5+6\end{array}$ & $\begin{array}{l}8 \cdot 54 \\
8 \cdot 05 \\
8 \cdot 41 \\
8 \cdot 51\end{array}$ & $\begin{array}{l}8 \cdot 13 \\
9 \cdot 61 \\
9 \cdot 41 \\
9 \cdot 16\end{array}$ & $\begin{array}{l}8 \cdot 22 \\
7 \cdot 51 \\
9 \cdot 54 \\
9 \cdot 62\end{array}$ & $\left.\begin{array}{l}8 \cdot 10 \\
7 \cdot 23 \\
7 \cdot 82 \\
6 \cdot 99\end{array}\right\}$ & Present study \\
\hline
\end{tabular}

needs of 'practically all healthy persons in the population'. NACNE (1983) gives recommendations on fat and dietary fibre. Table 8 shows the RDA appropriate for comparison with the mean intakes from this study.

\section{Energy}

Energy intakes were greater in pregnancy than when non-pregnant. This observation holds good even when lactating and dieting subjects' values are removed from group 3, leaving a group who are neither dieting nor lactating and may therefore be taken as non-pregnant controls. The increase over these non-pregnant 'control' levels was greater for the Edinburgh than for the London women. The lower energy intake of the Edinburgh group in round 2 and post-partum, compared with the London group $(P<0.01)$, was noteworthy. More London women complained of nausea and food 'aversions' in early pregnancy, and this may explain their initially low intakes, but there is no obvious reason why they should have had higher intakes subsequently.

Bull (1985) found the mean intake of young dieting women to be $6.95 \mathrm{MJ}(1661 \mathrm{kcal}) / \mathrm{d}$. Although it was not unexpected that non-lactating women should be slimming, it was surprising to find women attempting to lose weight whilst breast-feeding. The low energy intake $(6.36 \mathrm{MJ} /(1521 \mathrm{kcal}) / \mathrm{d})$ of the six London women who were dieting and lactating raises questions about the adequacy of their diets.

According to the National Food Survey (MAFF, 1985) the energy consumption of the UK population has declined over the past 10 years; this is a confounding factor when considering the energy intakes of pregnant women. Table 9 shows the results of a series of studies done since 1944, which generally show a downward trend in intakes. Both Whitehead et al. (1981) and Durnin et al. (1985) found that pregnant women consumed less energy than the recommended amounts, yet produced infants with satisfactory birth weights. However, Doyle et al. (1982), in their study of mothers in low socio-economic groups whose energy intakes were very low $(<7.4 \mathrm{MJ}(1772 \mathrm{kcal}) / \mathrm{d})$ found an increased incidence of low birth weight. The present study confirms the findings of those cited 
previously, demonstrating energy intakes lower than the RDA, in pregnancy, in lactation, and in the "control' group. The incidence of low birth weight was only $2 \%$ in a sample of 234 and did not vary with social class; there were no perinatal deaths. This sample is far too small for conclusions to be drawn about mortality rate, but it appears that 'low' energy intakes were adequate for normal fetal growth, and we conclude that the RDA is set unrealistically high.

The failure to detect a consistent social-class gradient during pregnancy is surprising. However, the general decline in mean intakes, and the emphasis on a 'healthy' diet being low in fat and sugar may well be the reason why women in social classes $1+2$ did not have significantly higher intakes than others.

\section{Protein}

It is apparent (Table 8) that all groups of women in the present study consumed amounts well above the RDA, and the average contribution of protein to dietary energy was $14 \%$. Examination of protein: energy ratios shows that the London and Edinburgh post-partum dieters consumed 15 and $16 \%$ of dietary energy as protein respectively, reflecting the widespread belief that protein foods are less fattening than 'starch' and fat. The Londoners consumed more protein than the Edinburgh group during pregnancy, but intakes of both groups were so high relative to the RDA that regional differences are not of great importance. No significant social-class differences in protein intake were detected.

\section{Fat}

Subjects in the present study had high-fat intakes, similar to those of other groups (Smithells et al. 1977, Doyle et al. 1982). The percentage of dietary energy derived from fat (39-40\% in London, $40-42 \%$ in Edinburgh) was slightly lower than the National Food Survey reports for England (43.3\%) and Scotland (42\%) (MAFF, 1985). Although this percentage was higher in Edinburgh, the Londoners ate more fat in absolute terms. The same pattern of higher absolute fat intakes in London, with lower percentages of dietary energy, emerged when dieting and non-dieting subjects were compared. The mean 'dieting' Edinburgh intake of $74.0 \mathrm{~g} / \mathrm{d}$ (43\% energy) was unexpected for a group claiming to be slimming, and the understanding by this group of the nature of a low-energy diet is open to question. The lowest energy intake from fat was $36 \%$, in the dieting non-lactating London group. None of the groups in the study reached the $35 \%$ level recommended by the DHSS (1984) or the $30 \%$ of NACNE (1983).

\section{Fibre}

Taking the intakes of the non-dieting, non-lactating women as a control, the subjects in the present study can be seen to have increased their fibre intakes during pregnancy and lactation. Nevertheless, these increased intakes are far below current recommendations (NACNE, 1983). The lower relative intakes of the Edinburgh group may be a function of smaller ranges and varieities of foods being available, and increased use of processed foods (E. Wheeler, C. Schofield and J. Stewart, unpublished results). The social class differences in fibre intake may reflect differences in knowledge of current health education messages (Schofield et al. 1987).

\section{Conclusion}

The surprising finding from the present study is that regional differences in energy, protein, fat and fibre intake outweighed social-class differences. Two possible explanations apply for both pregnancy and lactation. One is that the middle-class women were the most "health conscious' and controlled their fat and fibre intakes. This would tend to cancel out the 
'traditional' high-energy intake of their class. The other is that the general downward trend which is taking place in energy intakes is obscuring social-class differences. Both explanations may apply. An additional explanation, after pregnancy, would be that more middle-class women are genuinely dieting to regain their shape.

The RDA for nutrients and energy need to be reassessed in the light of increasing evidence of 'low' energy and protein intakes and satisfactory birth weights. It appears from this and other surveys that a recommended intake of $8.4 \mathrm{MJ}(2000 \mathrm{kcal}) / \mathrm{d}$ would be adequate for pregnancy and lactation in groups of healthy women in the UK. At $10 \%$ of dietary energy, this would imply a protein intake of $50 \mathrm{~g} / \mathrm{d}$. No study in the UK has shown a mean intake as low as this, but the current Food and Agriculture Organization/World Health Organization/United Nations University (1985) 'safe levels' of protein intake for a $60 \mathrm{~kg}$ woman, who becomes pregnant, is $51 \mathrm{~g} / \mathrm{d}$. There seems no reason to recommend intakes higher than those found in healthy women. It appears from the present study that the concept of 'dieting' is a flexible one, to say the least, and does not necessarily involve reduced fat intake. This point may be of interest to health educators.

The authors wish to acknowledge financial support, and assistance in computing, from the Ministry of Agriculture, Fisheries and Food; and the help and cooperation given by $\mathrm{Dr}$ Oliver Brooke, Dr Frank Johnstone and their colleagues, and the pregnant women in London and Edinburgh.

\section{REFERENCES}

Abraham, R., Campbell-Brown, M., Haines, A. P., North, W. R. S., Hainsworth, V. \& McFadyen, I. R. (1985). Human Nutrition: Applied Nutrition 39A, 23-35.

Black, A. E., Wiles, S. J. \& Paul, A. A. (1986). British Journal of Nutrition 56, 59-72.

Bransby, E. R., Daubney, C. G. \& King, J. (1944). British Journal of Nutrition 2, 89-110.

Bull, N. L. (1985), Human Nutrition: Applied Nutrition 39A Suppl.

Campbell-Brown, M. (1982). Proceedings of the Tenth Study Group of the Royal College of Obstetrics and Gynaecology. London: Royal College of Obstetrics and Gynaecology.

Campbell-Brown, M., Johnstone, F. D. \& Grieve, J. F. K. (1986). Proceedings of the Nutrition Society 45, 90A.

Department of Health and Social Security (1979). Report on Health and Social Subjects no. 15. London: H.M. Stationery Office.

Department of Health and Social Security (1984). Diet and Cardiovascular Disease, Committee on Medical Aspects of Food Policy. Report of the Panel on Diet in Relation to Cardiovascular Disease. London: H.M. Stationery Office.

Doyle, W., Crawford, M. A., Laurance, B. M. \& Drury, P. (1982). Human Nutrition: Applied Nutrition 36A, 95-106.

Durnin, J. V. G. A., Mckillop, F. M., Grant, S. \& Fitzgerald, G. (1985). Lancet ii, 823-825.

Food and Agriculture Organization/World Health Organization/United Nations University. (1985). Technical Report Series no. 724. Geneva: World Health Organization.

Marr, J. W. (1971). World Review of Nutrition and Dietetics 13, 105-164.

Ministry of Agriculture, Fisheries and Food (1985). Annual Report of the National Food Survey Committee (1983). London: H.M. Stationery Office.

National Advisory Committee on Nutrition Education (1983). Proposals for Nutritional Guidelines for Health Education in Britain. London: Health Education Council.

Office of Population Censuses and Surveys (1980). Classification of Occupations. London: H.M. Stationery Office.

Office of Population Censuses and Surveys (1981). Regional Trends 1979-80. London: H.M. Stationery Office.

Office of Population Censuses and Surveys (1984). OPCS Monitor DH3 84/6. London: H.M. Stationery Office.

Office of Population Censuses and Surveys (1985). OPCS Monitor DH3 85/5. London: H.M. Stationery Office.

Paul, A. A. \& Southgate, D. A. T. (1978). McCance and Widdowson's The Composition of Foods. London: H.M. Stationery Office and Elsevier/North Holland, Biomedical Press.

Paul, A. A., Southgate, D. A. T. \& Russell, J. (1980). First Supplement to McCance and Widdowson's The Composition of Foods. London: H.M. Stationery Office. 
Pickard, B. M. (1983). Nutrition and Food Science January/February, 20-22.

Schofield, E. C., Wheeler, E. F. \& Stewart, J. (1987). Human Nutrition: Applied Nutrition (In the Press).

Smithells, R. W., Ankers, C., Carver, M. E., Lennon, D., Schorah, C. J. \& Sheppard, S. (1977). British Journal of Nutrition 38, 497-506.

Snedecor, G. W. \& Cochran, W. G. (1967). Statistical Methods, 6th ed. Ames, Iowa: Iowa State University Press.

Thomson, A. M. (1959). British Journal of Nutrition 13, 190-204.

Thomson, A. M., Hytten, F. E. \& Bilewicz, W. Z. (1970). British Journal of Nutrition 24, 565-572.

Whitehead, R. G., Paul, A. A., Black, A. E. \& Wiles, S. J. (1981). Food and Nutrition Bulletin Suppl. 5, $259-265$. 